\title{
The Limits of Hearing: Historical and Contemporary Perspectives on Vocal Materiality and Expression
}

\author{
CLARA LATHAM
}

\section{Introduction}

In recent years, the human voice has emerged as a productive and provocative interdisciplinary paradigm, an expansive playing field where musicological studies of song, linguistic studies of language, laryngological studies of the vocal apparatus, and a wide range of work throughout media studies, communications, law, and philosophy can be placed into fruitful dialogue. ${ }^{1}$ An object of philosophical contemplation since at least the time of Aristotle, the voice has regularly been linked to notions of presence, essence, agency, and truth. ${ }^{2}$ At the same time, vocal practices are shaped by cultural, historical, and physiological forces, which give local inflections to the rich connotative field surrounding the voice. A wave of new and forthcoming studies of voice explore this field, drawing attention to acoustic and metaphorical valences of vocal practices in multiple registers. ${ }^{3}$

The essays in this special issue of Music and Politics contribute to this conversation by placing voice in a dynamic relation to audition/listening; focusing on the acts of labor, friction, and strain that bring voices into audibility; and charting the political stakes of these acts. We ask how one can account for the voice in cases where its acoustic presence is compromised by specific physiological, sociocultural, and environmental contingencies. Voices before the age of recording, voices that have been damaged by illness or war, and voices whose audibility is inhibited by physical or cultural constraints demand a rethinking of the relationship between the voice, sound, audition, aesthetics, and politics. What happens in situations where the conjoined labor of vocalists and auditors becomes challenging, onerous, dangerous, terrifying, or even ruinous? What happens when clinical voices become politicized, or when aesthetic ideals are achieved through practices that produce vocal failure and non-normative sounds? By straining to make sense of these extreme cases, we will illuminate a number of under-theorized dimensions of vocal performance and auditory attunement; their affective, political, ethical, and aesthetic power; and the conditions that shape, amplify, and delimit that power.

The turn to voice must, of course, grapple with the problems of voice that are inherited from

\footnotetext{
${ }^{1}$ This introduction is the product of a great deal of fruitful exchange with my co-editor J. Martin Daughtry, as well as the stimulating discourse of the conference The Limits of Hearing: Historical and Contemporary Perspectives on Vocal Materiality and Expression, co-organized by myself, J. Martin Daughtry, and Lauren Ninoshvili in Spring 2014, and sponsored by the New York University Music Department and the NYU Humanities Initiative Working Group "Contemplating Voice".

2 Amanda Weidman, “Anthropology and Voice," Annual Review of Anthropology 43 (2014), 37-51; J. Martin Daughtry, "Afterword: From Voice to Violence and Back Again," in Music, Politics, and Violence, ed. Kip Pegley and Susan Fast (Middletown, CT: Wesleyan University Press, 2012), 243-264.

${ }^{3}$ See for example the Oxford Handbook of Voice Studies, edited by Nina Sun Eidsheim and Katherine L. Meizel (forthcoming); Twentieth Century Music, Special Issue on n Eids,' edited by Julian Johnson and Robert Adlington (forthcoming); and Martha Feldman et al., "Why Voice Now?," Journal of the American Musicological Society 68.3, (2015), 653-685.
} 
deconstruction. In the Western metaphysical and linguistic traditions, voice is the avatar of agency and identity. Derrida's well-known 1967 critique of phonocentrism and the voice dismantles the cohesion of voice as metaphysics, urging theorists of voice to reconfigure agential vocality as critically spaced from its metaphysical status. ${ }^{4}$ Both Amanda Weidman and Brian Kane have recently traced two strategies that seek to avoid the trap of reconstituting the metaphysical voice. ${ }^{5}$ Drawing liberally on Lacan, the first strategy presents voice not as the affirmation of a self-contained subject, but as evidence of the excess of that subject, always figured as a "part object" that keeps subjectivity tied to the social unconscious. ${ }^{6}$ Another approach focuses not on the voice as an extension of subjectivity, but as a source of the radical individuality of the sounding agent. Here we could include Barthes' idea that the source of pleasure (jouissance) in vocality is its "grain," the quality produced by a fusion of the singing body, the material voice that emerges from it, and the phonemes of the mother tongue that this voice shapes. ${ }^{7}$ Adriana Cavarero similarly focuses on the voice as a radical source of individuality, though she routes this through the identity of the speaker, rather than the materiality of the speech. ${ }^{8}$

The essays in this collection take yet another approach, investigating voice through thick description that produces deeply-situated knowledge about particular voices at the limits of hearing. Together, they advance a set of nuanced interpretations of various vocal "failures." Several of the essays deal with moments of physiological failure-such as the compromised voices of Marshallese bodies that were subjected to the U.S. government's nuclear testing on Bikini Atoll, or the deafness that informed Thomas Edison, the "father" of sound reproduction technology. Others grapple with the aestheticization of techniques that are misread as failures, such as those that can be found in the compromised voice of experimental avant-garde composer Alvin Lucier, whose vocal tic is the subject of his famous work "I am sitting in a room;" practitioners of soundsinging like Paul Dutton; and eighteenth-century castrato Luigi Marchesi. This somewhat disparate-seeming collection of subjects pursues a unified question about aesthetic epistemologies when they are directed toward voices that are rendered inaudible by physiological and political conditions.

David Samuels' piece reveals that Thomas Edison framed his hearing loss not as a tragic development, but rather as an adaptive quality in a progressive relation to hearing. This gambit presents an inverted version of the axiom that the ideological construct of modernity is isomorphically linked to a normative form of ableism. In this critical reading of the relationship between ableism and progress, deafness is not a handicap but a harbinger of the integrated landscape of modernity, in which human disability is a given condition that is corrected by ever-improving technologies. Herein lies one take on the nexus of voice, audition, situated politics, and aesthetic value.

The relationship between vocal technologies, compromised bodies, and aesthetic value is further illuminated by the figure of the castrato, who is at the same time improved and ruined by the technology of castration. In her novel study of the famed Milanese castrato Luigi Marchesi, Talya Berger argues that transcriptions of live performances by Marchesi are in fact sound recordings from the eighteenth century.

\footnotetext{
${ }^{4}$ Jacques Derrida, La Voix et la Phénomène (Paris: Presses Universitaires de France, 1967).

${ }^{5}$ Brian Kane, "The Model Voice," in Feldman et al., "Why Voice Now?," The Fournal of the American Musicological Society 68 (2015, 653-685; and Amanda Weidman, “Anthropology and Voice," Annual Review of Anthropology 43 (2014), 37-51.

${ }^{6}$ See Mladen Dolar, $A$ Voice and Nothing More (Cambridge, MA: MIT Press, 2006). For a critique of this approach to voice, see Brian Kane, Sound Unseen: Acousmatic Sound in Theory and Practice (Oxford: Oxford University Press, 2014 ), 180-222.

${ }^{7}$ Roland Barthes, "The Grain of the Voice," in Image, Music, Text, ed. and trans. Stephen Heath (New York: Hill and Wang, 1977), 179-189.

${ }^{8}$ See Adriana Cavarero, For More Than One Voice: Toward a Philosophy of Vocal Expression (Stanford, CA: Stanford University Press, 2005).
} 
This assertion echoes Patrick Feaster's claim that if we extend the definition of sound recording beyond the act of actually hearing the recording, sound recordings actually include visual representations of sound that predate the era of its mechanical reproduction. ${ }^{9}$ Feaster uses contemporary digital technologies to produce audio from historic “pictures of sound." Berger's assertion pushes Feaster's argument further by considering transcriptions of Marchesi to be sound recordings themselves. Reaching into the depths of the archive to produce a rich portrait of this virtuoso artist, Berger confronts and extends the limits of what can be heard in the historical record.

Chris Tonelli's contribution analyzes audience responses to the practice of soundsinging (his preferred term for what others gloss as "extended vocal techniques") through the framework of disability studies. Through his fieldwork with soundsingers, Tonelli unveils the ways in which normative assumptions about appropriate vocal practices structure the aesthetic hierarchies that constitute "good singing." Tonelli's study of the space between the value of able bodies and what constitutes valuable song produces a curious tension, because his own ethnographical method is brought into relief as an aesthetic practice.

This tension between the medically-pathologized voice and the aestheticized voice is the subject of Zeynep Bulut's piece about the practice of using "abnormal" speech in twentieth-century European avantgarde and American experimental music, but where Tonelli's method is ethnographic, Bulut's is critical. Both authors are invested in locating the point of suture between irregular vocality and ethical inscription in embodied experiences of listening, providing complementary trajectories towards that goal.

Jessica Schwartz's piece "Voice and Nuclear Colonialism" pursues the politics of listening to voices beyond the limits of hearing by collapsing the distinction between the aesthetic and political dimensions of vocal failure. Schwarz argues that by listening to Marshallese voices on their own terms-the terms of the throat (büro)-one can escape the trappings of nuclear colonialism, an ideological enterprise that has worked to silence both the Marshallese people and their cultural histories for the better part of a century.

In all, we hope this issue will help generate a new set of questions about the often-overlooked conditions that naturalize some voices while pathologizing others, that place some performers' voices at the center of a metaphysics of transcendence while marginalizing others, and that encourage listeners to regard voices as objects that are separable from the precarious subjects who produce them. We thank Patricia Hall and the staff at Music \& Politics for helping us to work through these questions publicly, and we look forward to continuing the conversation with you, the readers, in this and other forums.

\footnotetext{
${ }^{9}$ See Patrick Feaster, Pictures of Sound: One Thousand Years of Educed Audio: 980-1980 (Atlanta: Dust-to-Dust Digital, 2012).
} 